Original Article

\title{
Evaluation of antibacterial activity of vitamin $C$ against human bacterial pathogens
}

\author{
Avaliação da atividade antibacteriana da vitamina C contra patógenos bacterianos \\ humanos
}

\author{
S. Mumtaz ${ }^{\mathrm{a}}$, S. Mumtaz ${ }^{\mathrm{a}}$, S. Alia* (1) H. M. Tahir ${ }^{\mathrm{a}}$, S. A. R. Kazmi ${ }^{\mathrm{b}}$ T. A. Mughalc and M. Younas ${ }^{\mathrm{d}}$ \\ ${ }^{a}$ Government College University, Department of Zoology, Applied Entomology and Medical Toxicology Laboratory, Lahore, Pakistan \\ ${ }^{\mathrm{b}}$ Government College University, Department of Chemistry, Lahore, Pakistan \\ 'Department of Zoology, Women University of Azad Jammu and Kashmir, Bagh, Pakistan \\ dUniversity of Lahore, Institute of Molecular Biology and Biotechnology, Lahore, Pakistan
}

\begin{abstract}
Now a day's multidrug resistance phenomenon has become the main cause for concern and there has been an inadequate achievement in the development of novel antibiotics to treat the bacterial infections. Therefore, there is an unmet need to search for novel adjuvant. Vitamin $C$ is one such promising adjuvant. The present study was aimed to elucidate the antibacterial effect of vitamin $\mathrm{C}$ at various temperatures $\left(4^{\circ} \mathrm{C}, 37^{\circ} \mathrm{C}\right.$ and $\left.50^{\circ} \mathrm{C}\right)$ and $\mathrm{pH}$ $(3,8$, and 11$)$, against Gram-positive and Gram-negative bacteria at various concentrations $(5-20 \mathrm{mg} / \mathrm{ml})$ through agar well diffusion method. Growth inhibition of all bacterial strains by vitamin $C$ was concentration-dependent. Vitamin C significantly inhibited the growth of Gram-positive bacteria: Bacillus licheniformis ( $25.3 \pm 0.9 \mathrm{~mm}$ ), Staphylococcus aureus ( $22.0 \pm 0.6 \mathrm{~mm}$ ), Bacillus subtilis $(19.3 \pm 0.3 \mathrm{~mm}$ ) and Gram-negative bacteria: Proteus mirabilis $(27.67 \pm 0.882 \mathrm{~mm})$, Klebsiella pneumoniae $(21.33 \pm 0.9 \mathrm{~mm})$, Pseudomonas aeruginosa $(18.0 \pm 1.5 \mathrm{~mm})$ and Escherichia coli $(18.3 \pm 0.3 \mathrm{~mm})$. The stability of vitamin $\mathrm{C}$ was observed at various $\mathrm{pH}$ values and various temperatures. Vitamin $\mathrm{C}$ showed significant antibacterial activity at acidic $\mathrm{pH}$ against all bacterial strains. Vitamin $\mathrm{C}$ remained the stable at different temperatures. It was concluded that vitamin $C$ is an effective and safe antibacterial agent that can be used in the future as an adjunct treatment option to combat infections in humans.
\end{abstract}

Keywords: agar well diffusion method, antibacterial activity, vitamin C, Pseudomonas aeruginosa.

\begin{abstract}
Resumo
Agora, a resistência antimicrobiana de um dia em patógenos aos antibióticos tornou-se a principal causa de preocupação e houve uma realização inadequada no desenvolvimento de novos antibióticos para tratar infecções bacterianas. Portanto, há uma necessidade de pesquisar um novo adjuvante, e a vitamina $C$ é um desses adjuvantes promissores. $\mathrm{O}$ objetivo do presente estudo foi elucidar o efeito antibacteriano da vitamina $\mathrm{C}$ em diferentes temperaturas $\left(4^{\circ} \mathrm{C}, 37^{\circ} \mathrm{C}\right.$ e $\left.50^{\circ} \mathrm{C}\right)$ e $\mathrm{pH}(3,8$ e 11$)$, contra Gram-positivos e Gram-cepas bacterianas negativas em várias concentrações (5-20 mg / ml) através do método de difusão em ágar bem. A inibição do crescimento de todas as cepas bacterianas pela vitamina $C$ era dependente da concentração. A vitamina C inibiu significativamente o crescimento de bactérias Gram-positivas: Bacillus licheniformis (25,3 \pm 0,9 mm), Staphylococcus aureus $(22,0 \pm 0,6 \mathrm{~mm})$, Bacillus subtilis $(19,3 \pm 0,3 \mathrm{~mm})$ e bactérias Gram- negativas: Proteus mirabilis $(27,7 \pm 0,9 \mathrm{~mm})$, Klebsiella pneumoniae (21,3 \pm 0,9 mm), Pseudomonas aeruginosa (18,0 $\pm 1,5 \mathrm{~mm})$ e Escherichia coli $(18,3 \pm 0,3 \mathrm{~mm})$. A estabilidade da vitamina $\mathrm{C}$ foi observada em vários valores de $\mathrm{pH}$ e várias temperaturas. $\mathrm{A}$ vitamina $\mathrm{C}$ mostrou atividade antibacteriana significativa em $\mathrm{pH}$ ácido contra todas as cepas bacterianas. A estabilidade da vitamina $\mathrm{C}$ permaneceu nas mesmas diferentes temperaturas $\left(4^{\circ} \mathrm{C}, 37^{\circ} \mathrm{C}\right.$ e $\left.50^{\circ} \mathrm{C}\right)$. Concluímos que a vitamina $\mathrm{C}$ é um agente antibacteriano eficaz e seguro que pode ser usado no futuro como uma opção de tratamento auxiliar para combater infecções em humanos, pois pode apoiar o sistema imunológico diretamente.
\end{abstract}

Palavras-chave: método de difusão em ágar, atividade antibacteriana, vitamina C, Pseudomonas aeruginosa.

\section{Introduction}

Vitamin $\mathrm{C}$ is an important antioxidant, free radical scavenger, pro-oxidant, and an antibacterial molecule that can modify the antimicrobial activity of various

antibiotics as well as significantly declines the adversative effects of reactive species (Kwiecinska-Pirog et al., 2019). Among the most common infections, urinary

*e-mail: dr.shaukatali@gcu.edu.pk

Received: January 02, 2021 - Accepted: February 23, 2021

This is an Open Access article distributed under the terms of the Creative Commons Attribution License, which permits unrestricted use, distribution, and reproduction in any medium, provided the original work is properly cited. 
tract infections (UTIs) especially among women are seen around the world. Various bacterial strains such as Klebsiella pneumoniae and E. coli have antibiotic resistance which results in more complications occur (Ahmed et al., 2019). Therefore, it is needed to treat various infections including urinary tract infections and vitamin $C$ is one of the cheap alternatives that have no adverse effects and easily available (Verghese et al., 2017). Hong et al. (2016) stated that high concentrations of vitamin C, particularly, possess immunomodulatory functions, and antimicrobial properties, therefore, decreasing the risk of infections. The antibacterial effect of vitamin C particularly, L- ascorbic acid has been found against various pathogenic organisms including Bacillus subtilis, Corynebacterium diphtheria, Enterococcus faecalis, and Staphylococcus aureus (Isela et al., 2013). It also prohibits the mycobacterium tuberculosis and Helicobacter pylori, which is responsible for carcinoma (Vilchèze et al., 2013). The pharmacological use of ascorbic acid is supposed to improve the role of the immune system and a precarious basal meditation of vitamin $C$ is crucial for an average and well-functional host resistance mechanism (Van Gorkom et al., 2018). Humoral and cellular immune responses might be reduced due to the deficiency of vitamin C (Jeong et al., 2014). Moreover, in humans and other experimental in vivo models, the influence of ascorbic acid on various immune cell populations has been revealed (Van Gorkom et al., 2019). In experimental studies, vitamin C treatment enhanced and promoted lymphocyte proliferation, natural killer cell activities, and chemotaxis besides its anti-inflammatory properties (Hemila, 2017). It is also observed that concentrations of vitamin $C$ are 10 - to 100 -fold higher in immune cells e.g., leukocytes than those measured in the plasma (Strohle et al., 2011). Furthermore, hydroxylase enzymes require vitamin $C$ as a cofactor to transcription of gene, cell signaling of immune system cells and the action of the hypoxia-inducible factors (Kuiper and Vissers, 2014). Vitamin C possesses an inhibitory influence against pathogens (Helicobacter pylori), in the gut, which is a recently recognized causal agent of sores (Namiot et al., 2020). Woo et al. (2010) reported that ascorbic acid could kill the strains of mycobacterium tuberculosis that are resistant to most other antibiotic drugs. In various studies, fruit juices containing vitamin $C$ were used as antimicrobials that reveal that vitamin $C$ act as an antibacterial agent (Opara et al., 2009).

The purpose of conducted research was to elucidate the antibacterial potential of vitamin C (L-ascorbic acid) against Gram-positive and Gram-negative bacterial pathogens and optimization of stability at different $\mathrm{pH}$ values and temperature.

\section{Materials and Methods}

\subsection{Bacterial strains and culture media}

Gram-positive $\{$ B. licheniformis (FCBP-SB-0019), B. subtilis (FCBP-SB-0223), S. aureus (FCBP-WB-0260), and Gram-negative bacterial strains K. pneumoniae (FCBP-PB-0047), pseudomonas aerguginosa (FCBP-PB-0083), E. coli (FCBP-SB-0011), and P. mirabilis (FCBP-PB-0043)\} were taken from Institute of Agricultural Sciences, University of The Punjab, Lahore, and the Microbiology Department, Government College University, Lahore, Pakistan. Nutrient broth (CM0001, OXOID LTD., and Agar CAS Nr: 9012-36-6 (Sigma- Aldrich Company) was used as a culture medium for the growth of bacteria. Vitamin $C$ (L-ascorbic acid, CAS Nr. 50-81-7) with molar mass (176.12 $\mathrm{g} / \mathrm{mol}$ ) was purchased from Sigma Aldrich Company. HCL $\left(\mathrm{CH}_{3} \mathrm{COOH}, \mathrm{M}=60.05 \mathrm{~g} / \mathrm{mol}\right.$, Merck KGaA Darmstadt, Germany) was used. Sodium hydroxide (NaOH, CAT No. S5881, Sigma-Aldrich, Saint Louis, MO 63103, USA) was used. Erythromycin with (Mfg. Lic. No. 000124) was purchased from Indus Pharma (Pvt. Ltd), and used as a positive control.

\subsection{Antibacterial test}

The antibacterial activities of vitamin $C$ were evaluated via agar well diffusion method against Gram-positive (B. licheniformis, S. aureus and B. subtilis and Gram-negative bacteria P. mirabilis, P. aeruginosa, K. pneumoniae, and E. coli) (Hwang et al., 2020). Briefly, freshly prepared bacterial growth or culture media was poured into the sanitized petri dishes in a laminar airflow. After solidifying, the petri dishes were incubated for $24 \mathrm{~h}$ at $37^{\circ} \mathrm{C}$. Then $50 \mu \mathrm{l}$ of nutrient broth containing test organisms was added into plates through a micropipette and spread over the whole petri plates with a spreader. Petri plates were air-dried under sterile conditions for $10 \mathrm{~min}$ and wells ( $5 \mathrm{~mm}$ diameter) were formed. In the remaining wells $50 \mu$ of test solution (vitamin C) with various concentrations ( $5 \mathrm{mg}, 10 \mathrm{mg}$, and $20 \mathrm{mg} / \mathrm{ml}$ ) was added via micropipette. Erythromycin $(5 \mathrm{mg} / \mathrm{ml}$ ) was added in one well as a positive reference standard and one well filled with water as a negative control. After $24 \mathrm{~h}$ of incubation at $37^{\circ} \mathrm{C}$, the zones of inhibition around the samples were calculated in with a graduated scale in millimeters $(\mathrm{mm})$. All samples were studied in triplicate. To support these obtained data, photographs of the inhibition zones were taken and a solution of vitamin C with various concentrations was tested to check the antibacterial effect against Gram-negative and Gram-positive pathogens.

\subsection{Stability of vitamin $\mathrm{C}$ at different temperatures and $\mathrm{pH}$}

Three autoclaved Eppendorf tubes were taken and $(20 \mathrm{mg} / \mathrm{ml})$ of vitamin C solution was added in each tube to evaluate the stability at various temperatures $\left(4^{\circ} \mathrm{C}, 37^{\circ} \mathrm{C}\right.$, and $\left.50^{\circ} \mathrm{C}\right)$. These three Eppendorf tubes were kept at $\left(4^{\circ} \mathrm{C}\right.$, $37^{\circ} \mathrm{C}$, and $50^{\circ} \mathrm{C}$ ) for $36 \mathrm{~h}$ (Aramwit et al., 2010; Ramos et al., 2019). The antimicrobial action of these samples was assessed after the incubation period, by using the agar well diffusion method against Gram- negative bacteria (K. pneumoniae, E. coli, P. aeruginosa and P. mirabilis and Gram-positive bacteria (B. subtilis, B. licheniformis, and S. aureus).

To record the stability of vitamin $\mathrm{C}$ at different $\mathrm{pH}$ values, three falcon tubes were taken and $20 \mathrm{mg} / \mathrm{ml}$ of vitamin $C$ solution was added to each tube. In one tube, $\mathrm{NaOH}$ was added until its $\mathrm{pH}$ became basic or $(\mathrm{pH} 8)$, and in the second tube, $\mathrm{HCl}$ (diluted) was added dropwise till its $\mathrm{pH}$ became 3 or acidic. Similarly, in the third falcon 
tube $\mathrm{pH}$ was adjusted via $\mathrm{pH}$ meter to basic/ $\mathrm{pH}$ (11) by adding $\mathrm{NaOH}$ (Aramwit et al., 2014).

\section{Statistical Analysis}

Results were tabulated as the means \pm SEM. Statistical analysis was carried out using SPSS (version 16) and the data were assessed by one-way analysis of variance (ANOVA), and Tukey's multiple comparison test. When the $P$-value was $<0.05$, values were deliberated to be statistically substantial.

\section{Results}

In the current research antibacterial activity of vitamin $C$ or L ascorbic acid at 5, 10 and $20 \mathrm{mg} / 1 \mathrm{ml}$ was determined against seven bacterial strains i.e., Gram-positive(S. aureus, B. subtilis, B. licheniformis and Gram- negative bacteria (K. pneumoniae, E. coli, P aeruginosa and P. mirabilis) by calculating the diameter of the zone of inhibitions. For all bacterial strains, outcomes of Tukey's test revealed that there was a significant variance $(p<0.05)$ in the antibacterial activity at 5,10 and $20 \mathrm{mg} / \mathrm{ml}$ of vitamin C. The highest zones of inhibition was observed at the highest concentration of vitamin C $(20 \mathrm{mg} / \mathrm{ml})$ with respect to 10 and $5 \mathrm{mg} / \mathrm{ml}$ of vitamin $C$ and positive control "erythromycin" ( $5 \mathrm{mg} / \mathrm{ml}$ ). No zones of inhibition were detected against negative control.
Table 1 shows that Gram-negative bacteria e.g., $P$. mirabilis showed the highest zones of inhibition (27.7 \pm 0.9$)$ when compared to other bacterial strains. For B. lichniformis zone of inhibition (25.33 \pm 0.882 ) was significantly larger than $B$. subtilis (19.3 \pm 0.3 ) at $20 \mathrm{mg} /$ $\mathrm{ml}$ concentration of vitamin $\mathrm{C}$. No zone of inhibition was found in the positive control group against $P$. aeruginosa, S. aureus and K. pneumoniae at $5 \mathrm{mg} / \mathrm{ml}$ of erythromycin which shows that these bacterial strains are resistant to antibiotic (erythromycin). S. aureus showed zones that were $4 \mathrm{~mm}$ bigger than shown by $E$. coli and $P$. areguinosa at the highest concentration $(20 \mathrm{mg} / \mathrm{ml})$ of vitamin C. These results showed that vitamin $C$ more reticent the growth of $S$. aureus than $P$. aeruginosa, E. coli and B. licheniformis.

Table 2 shows that when we measured the sensitivity at numerous temperatures $\left(4^{\circ} \mathrm{C}, 37^{\circ} \mathrm{C}\right.$, and $\left.50^{\circ} \mathrm{C}\right)$, all strains of bacteria showed the highest zone of inhibition at $4^{\circ} \mathrm{C}$ other than S. aureus and K. pneumoniae. Smallest zone of inhibition was calculated against all bacterial strains at $50^{\circ} \mathrm{C}$, which shows that as the temperature increased growth of inhibition decreased.

Table 3 showed that vitamin $\mathrm{C}$ showed the largest zone of inhibition at "acidic $\mathrm{pH}(3)$ " against all bacterial zones, while, no zone of inhibition was recorded at $\mathrm{pH}$ 11. $P$. aeruginosa showed the highest zone of inhibition (36.7 \pm 0.9 ) at acidic $\mathrm{pH}$ with regard to other bacterial strains. Tukey's test is showing a detail comparison of all pathogens. The zones of inhibition of bacterial growth were shown in Figure 1, Figure 2 and Figure 3.

Table 1. Comparison of zones of growth inhibition $(\mathrm{mm})$ of three concentrations of vitamin $\mathrm{C}(\mathrm{mg} / \mathrm{ml})$ to erythromycin against seven strains of bacteria.

\begin{tabular}{cccccc}
\hline Treatments & Negative control & Positive control & $\mathbf{5 ~} \mathbf{~ m g} / \mathbf{m l}$ & $\mathbf{1 0} \mathbf{m g} / \mathbf{m l}$ & $\mathbf{2 0} \mathbf{~ m g} / \mathbf{m l}$ \\
\hline B. subtilis & $0.0 \pm 0.0^{\mathrm{a}}$ & $18.3 \pm 0.3^{\mathrm{b}}$ & $9.7 \pm 0.9^{\mathrm{c}}$ & $13.0 \pm 0.6^{\mathrm{d}}$ & $19.3 \pm 0.3^{\mathrm{b}}$ \\
B. licheniformis & $0.0 \pm 0.0^{\mathrm{a}}$ & $18.3 \pm 0.3^{\mathrm{b}}$ & $15.7 \pm 0.7^{\mathrm{c}}$ & $20.0 \pm 0.6^{\mathrm{b}}$ & $25.3 \pm 0.9^{\mathrm{d}}$ \\
P. aeruginosa & $0.0 \pm 0.0^{\mathrm{a}}$ & $0.0 \pm 0.0^{\mathrm{a}}$ & $9.7 \pm .0 .3^{\mathrm{b}}$ & $13.3^{\mathrm{b}} 0.8^{\mathrm{c}}$ & $18.0 \pm 1.5^{\mathrm{d}}$ \\
E.coli & $0.0 \pm 0.0^{\mathrm{a}}$ & $12.3 \pm 0.3^{\mathrm{b}}$ & $10.3 \pm 0.3^{\mathrm{b}}$ & $15.3 \pm 0.3^{\mathrm{c}}$ & $18.3^{\mathrm{a}} \pm 0.3^{\mathrm{d}}$ \\
S. aureus & $0.0 \pm 0.0^{\mathrm{a}}$ & $0.0 \pm 0.0^{\mathrm{a}}$ & $11.7 \pm 0.9^{\mathrm{b}}$ & $16.7 \pm 0.3^{\mathrm{c}}$ & $22.0 \pm 0.6^{\mathrm{d}}$ \\
P. mirabilis & $0.0 \pm 0.0^{\mathrm{a}}$ & $26.0 \pm 0.6^{\mathrm{b}}$ & $15.0 \pm 0.6^{\mathrm{c}}$ & $20.7 \pm 0.8^{\mathrm{d}}$ & $27.7 \pm 0.9^{\mathrm{b}}$ \\
K. pneumoniae & $0.0 \pm 0.0^{\mathrm{a}}$ & $0.0 \pm 0.0^{\mathrm{a}}$ & $14.0 \pm 1.0^{\mathrm{b}}$ & $18.0 \pm 1.0^{\mathrm{c}}$ & $21.3 \pm 0.9^{\mathrm{c}}$ \\
\hline
\end{tabular}

Table 2. Antibacterial activity of vitamin $C$ at various temperatures.

\begin{tabular}{|c|c|c|c|}
\hline Bacterial strains & $4^{\circ} \mathrm{C}$ & $37^{\circ} \mathrm{C}$ & $50^{\circ} \mathrm{C}$ \\
\hline B. subtilis & $24.3 \pm 0.9^{a}$ & $20.3 \pm 0.9^{\mathbf{b}}$ & $18.3 \pm 0.9^{\mathbf{b}}$ \\
\hline B. licheniformis & $24.3 \pm .0 .3^{a}$ & $21.7 \pm 0.7^{\mathbf{b}}$ & $19.7 \pm 0.7^{\mathbf{b}}$ \\
\hline P. aeruginosa & $20.0 \pm 0.6^{a}$ & $17.7 \pm 0.9^{\mathrm{ab}}$ & $15.7 \pm 0.9^{\mathbf{b c}}$ \\
\hline S. aureus & $22.0 \pm 0.6^{a}$ & $25.0 \pm 0.6^{\mathbf{b}}$ & $21.7 \pm .0 .3^{\mathrm{a}}$ \\
\hline K. pneumoniae & $18.7 \pm 0.3^{a}$ & $21.0 \pm 0.6^{\mathbf{b}}$ & $17.3 \pm 0.7^{a}$ \\
\hline P.mirabilis & $25.0 \pm 0.6^{a}$ & $22.0 \pm 0.6^{\mathbf{b}}$ & $21.0 \pm 0.6^{\mathbf{b}}$ \\
\hline E. coli & $24.0 \pm 0.6^{a}$ & $15.7 \pm .0 .3^{b}$ & $13.3 \pm 0.7^{c}$ \\
\hline
\end{tabular}


Table 3. Antibacterial activity of vitamin $\mathrm{C}$ at various $\mathrm{pH}$ values.

\begin{tabular}{cccc}
\hline Bacterial strains & $\mathbf{p H ~ 3}$ & $\mathbf{p H ~ 8}$ & $\mathbf{p H ~ 1 1}$ \\
\hline B. subtilis & $34.7 \pm 1.5^{\mathrm{a}}$ & $16.3 \pm 1.8^{\mathrm{b}}$ & $0.0 \pm .0^{\mathbf{c}}$ \\
B. licheniformis & $31.3 \pm 0.9^{\mathrm{a}}$ & $11.3 \pm 0.9^{\mathrm{b}}$ & $0.0 \pm .0^{\mathbf{c}}$ \\
P. aeruginosa & $36.7 \pm 0.9^{\mathrm{a}}$ & $10.0 \pm 0.6^{\mathrm{b}}$ & $0.0 \pm .0^{\mathrm{c}}$ \\
S. aureus & $32.0 \pm 1.2^{\mathrm{a}}$ & $3.7 \pm 0.3^{\mathrm{b}}$ & $0.0 \pm .0^{\mathrm{c}}$ \\
K. pneumoniae & $32.0 \pm 1.2^{\mathrm{a}}$ & $3.7 \pm 0.3^{\mathrm{b}}$ & $0.0 \pm .0^{\mathrm{c}}$ \\
P. mirabilis & $33.7 \pm 0.9^{\mathrm{a}}$ & $10.7 \pm 0.3^{\mathrm{b}}$ & $0.0 \pm .0^{\mathrm{c}}$ \\
E. coli & $31.7 \pm 1.5^{\mathrm{a}}$ & $4.3 \pm 0.9^{\mathrm{b}}$ & $0.0 \pm 0^{\mathrm{c}}$ \\
\hline
\end{tabular}
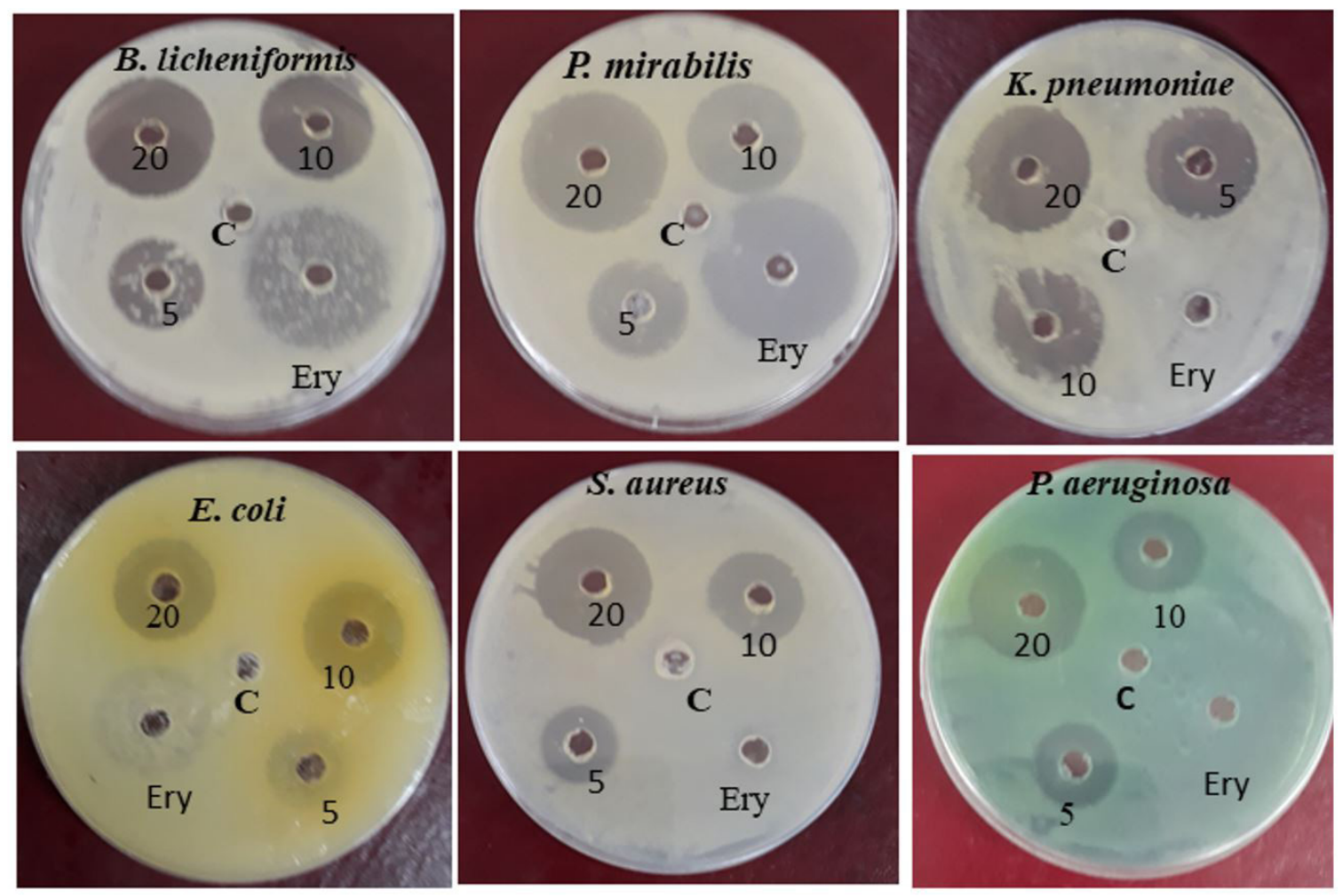

Figure 1. Zones of inhibition at different concentrations of vitamin $\mathrm{C}$. $\mathrm{C}$ denotes the negative control $\left(\mathrm{dH}_{2} \mathrm{O}\right)$, Ery, indicates the erythromycin (positive control).

\section{Discussion}

Now a day's antimicrobial resistance in bacterial strains to most common antibiotics has become the main cause for concern (Sweileh et al., 2018). In the current research, we evaluate the antibacterial effect of vitamin $C$ against Gram-positive bacterial strains (S aureus, B. subtilis, $B$. licheniformis, and Gram-negative bacterial strains K. pneumoniae, E. coli, P. aeruginosa, and P. mirabilis. Our results were supported by the previous studies (Golonka et al., 2017; Mehmeti et al., 2013). In the 1930s, the antimicrobial effect of ascorbic acid has been known against Mycobacterium tuberculosis, which is responsible to cause tuberculosis in humans (Simmons et al., 2018). In the conducted research, vitamin $C$ inhibited bacterial growth at each concentration. However, the largest inhibition zones against both Gram- positive and Gram-negative bacteria were found at the highest concentration $(20 \mathrm{mg} / \mathrm{ml})$ of vitamin C. Similar findings were observed by Verghese et al. (2017). In previous studies, it was stated that higher concentrations of ascorbic acid showed the largest zones of inhibition in both Gram positive-bacteria S. aureus and Gram negative-bacteria E. coli. Al-Talib et al., (2013), reported that in $S$. aureus the average zone of inhibition was larger than that for E. coli. For both bacterial species, the zones of inhibition decreased with each consecutive dilution. In the negative control group, no zones of inhibition were observed confirming that ascorbic acid is 

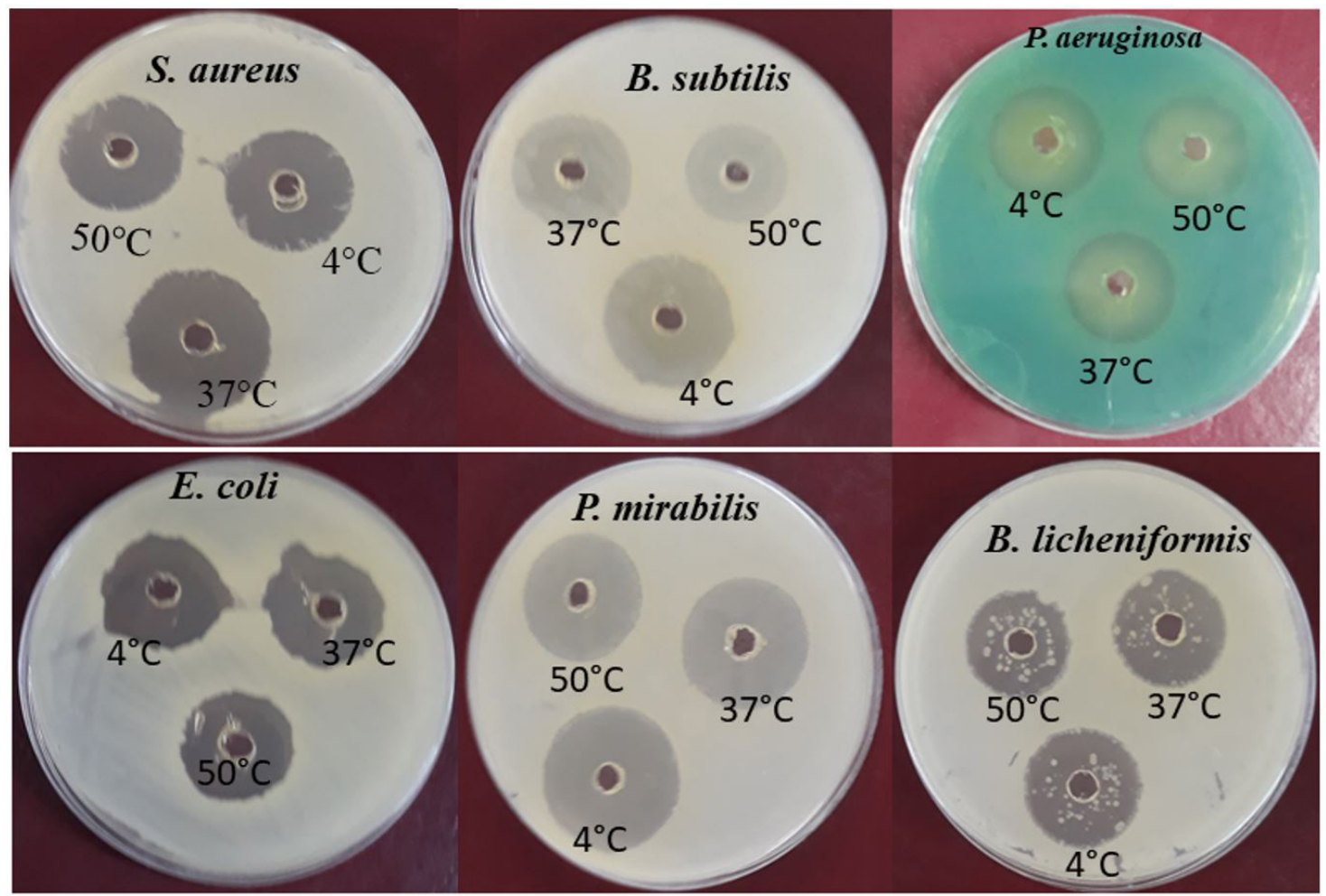

Figure 2. Zones of growth inhibition at different temperature against Gram-positive and Gram-negative pathogens.
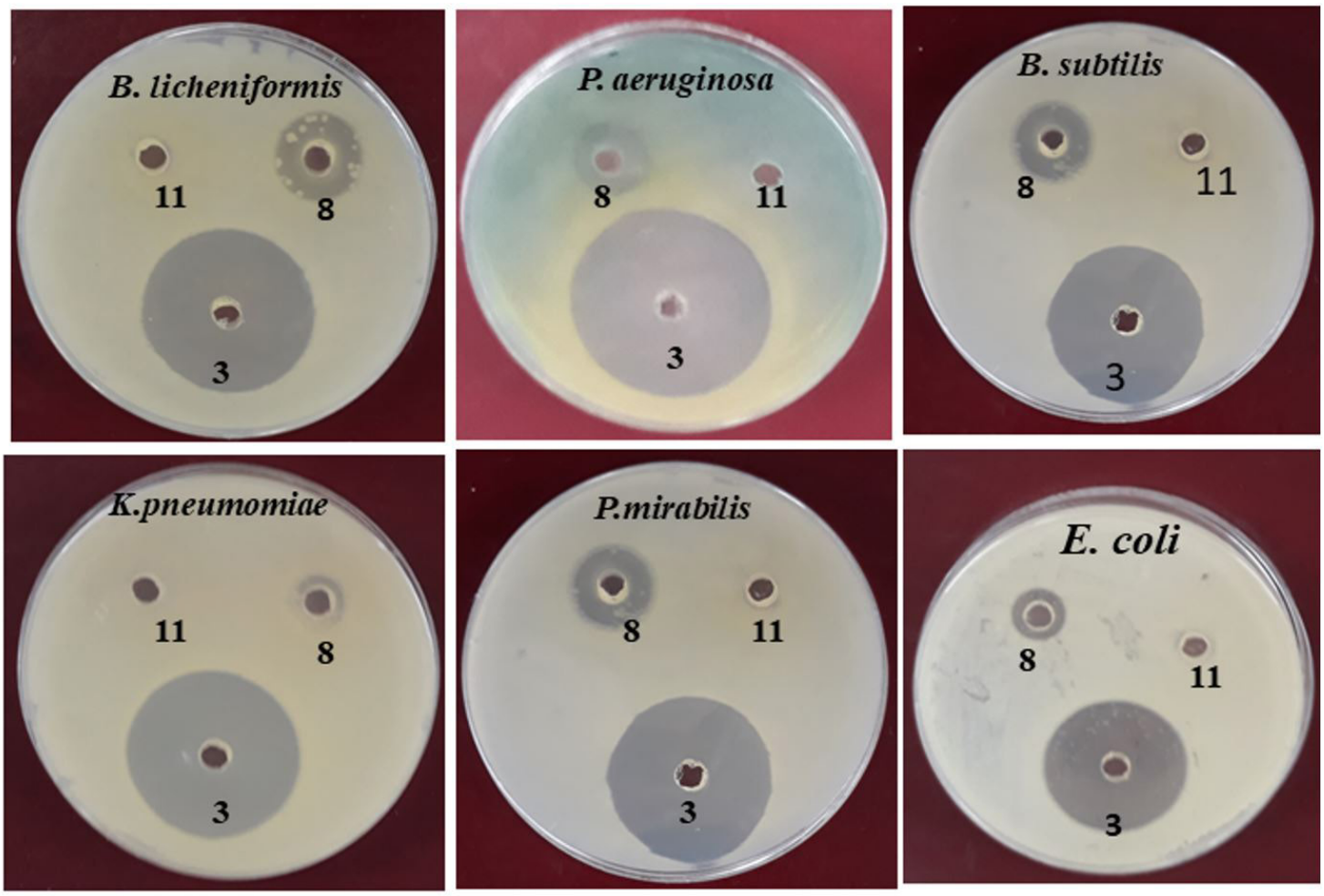

Figure 3. Zones of inhibition at different $\mathrm{pH}$ values. 
an antimicrobial factor (Al-Talib et al., 2013). Similar results were found in our study which supports that antibacterial effects of vitamin C can be a concentration-dependent for both Gram-negative and Gram-positive strains e.g., K. pneumoniae, E. coli and S. aureus, respectively (Majtan et al., 2020). In vitro studies showed that L-ascorbic acid could prevent the growth of Pseudomonas aeruginosa at $0.31 \mathrm{mg} / \mathrm{mL}$ concentration. However, at low concentration $(0.15 \mathrm{mg} / \mathrm{mL})$ it can also prohibit the growth of S. aureus and E. faecalis, but significant zone of inhibition was found at highest concentration $(0.31 \mathrm{mg} / \mathrm{mL})$ than $(0.15 \mathrm{mg} / \mathrm{mL})$ concentration (Golonka et al., 2017; Mehmeti et al., 2013). It is reported that vitamin C-deficient guinea pigs treated with tuberculosis sputum that results in intestinal tuberculosis occur while, tuberculosis was not found in vitamin C treated guinea pigs (Mousavi et al., 2019).

In the conducted research, we also assessed the stability of vitamin $\mathrm{C}$ at various temperatures $\left(4^{\circ} \mathrm{C}, 37^{\circ} \mathrm{C}\right.$, and $\left.50^{\circ} \mathrm{C}\right)$. Antibacterial activity of vitamin $\mathrm{C}$ remained the same at these temperatures, which showed that vitamin $C$ is a thermostable product (Ranjan et al., 2012). In the conducted research, vitamin $C$ significantly inhibited the growth of E. coli, P.mirabilis, P. aeruginosa, B. lichniformis, and $B$. subtilis at $4^{\circ} \mathrm{C}$. As the temperature increased e.g., at $50{ }^{\circ} \mathrm{C}$, vitamin $\mathrm{C}$ showed smaller zones of inhibition against all bacterial strains which showed that antibacterial activity of vitamin C is maximum at low to moderate temperatures. Other researchers have evaluated the same results; they also found that vitamin $\mathrm{C}$ showed maximum antibacterial activity at $25^{\circ} \mathrm{C}$, as compared to $85^{\circ} \mathrm{C}$ against $S$. aureus and E. coli (Ramos et al., 2019). Our results are also consistent with Ranjan et al. (2012), they stated the antimicrobial action of cinnamon extract as well as aqueous garlic against E. faecalis, S. aureus, E. Coli and Proteus mirabilis at $40{ }^{\circ} \mathrm{C}$, $60{ }^{\circ} \mathrm{C} 80{ }^{\circ} \mathrm{C}, 100^{\circ} \mathrm{C}$ and $120^{\circ} \mathrm{C}$. The maximum growth of inhibition was calculated at $40^{\circ} \mathrm{C}$ with a zone of inhibition $(1.5 \mathrm{~mm})$ with respect to $80^{\circ} \mathrm{C}$ and $100^{\circ} \mathrm{C}(1.3$ and $1.1 \mathrm{~mm})$ correspondingly (Hamadou et al., 2020).

In the conducted research, it also analyzed the antibacterial action of vitamin $\mathrm{C}$ at different $\mathrm{pH}$. In this research, we observed maximum zones of inhibition against all bacterial strains at acidic $\mathrm{pH}$. The Zone of inhibition was smaller towards the basic $\mathrm{pH}$. Pseudomonas aeruginosa showed the highest zone of inhibition $(36.7 \pm 0.9)$ at acidic pH. Hindi and Chabuck (2013) also stated that citrus lemon extracts revealed a substantial antibacterial action against all microbes. This significant inhibition might be due to the acidic $\mathrm{pH}$ of lemon extract that can affect the active sites of enzymes and it will modify the charges of the amino acids that establish the peptidoglycan cell wall. Abdullah (2009) also reported that the juice of citrus lemon significantly repressed the growth of K. pneumoniae and S. aureus with zones of inhibition $13.3 \mathrm{~mm}$ and $17.4 \mathrm{~mm}$ correspondingly. Our results are consistent with Hindi and Chabuck (2013) and Abdullah (2009). Moreover, minor inhibitory influence on the growth of S. aureus had been found via pH-neutralized vitamin C (Kallio et al., 2012). The synergistic effect of L- ascorbic acid combination with deferoxamine has also been found against Gram-negative bacilli such as K. pneumoniae, E. coli and P. mirabilis as well as Gram-positive cocci, e.g., S. aureus, and S. epidermidis.
Similarly, synergistic antibacterial effects of ascorbic acid and natural extracts e.g., white tea pomegranate rind extracts and quercetin was found against $S$. aureus (Holloway et al., 2011).

In a few clinical settings, the capability of vitamin $C$ to prevent the growth of bacteria has been confirmed. Biswas et al. (2013) stated that in volunteers, supplementation of Vitamin C declined the facts of E. faecalis and E. coli in samples of urine. Previous studies revealed that S. aureus, and $P$. aeruginosa that were formerly resilient to sulfadiazine only while, scattering of $1 \%$ sulfadiazine cream along with Vitamin C, on bedsore aided to eliminate these pathogens (Przekwas et al., 2020). Verghese et al. (2017) stated that vitamin $C$ showed a substantial inhibiting action in the form of L- ascorbic acid on the growth of E. coli whereas; when vitamin $C$ was used in the form of sodium ascorbate, no substantial inhibition outcome was found.

Then, our data suggest that ascorbic acid could be an antibiotic modifier. In past studies it was reported that the zone of inhibition in K. pneumoniae and E. coli strains was not found at low concentrations of vitamin $C$ whereas, zone of inhibition $80-100 \mathrm{mg} / \mathrm{ml}$ meditation of vitamin C was observed (El-Gebaly et al., 2012). Similar results were observed in our conducted research. As the concentration of vitamin C decreased such as at $5 \mathrm{mg} / \mathrm{ml}$, smallest zones of inhibition were calculated against K. pneumonia, and E. coli.

\section{Conclusion}

This study concluded that vitamin $C$ is an effective and safe antibacterial agent. Vitamin $C$ significantly repressed the growth of Gram-negative and b Gram-positive bacterial strains (K. pneumoniae, E. coli, P. aeruginosa, $P$. mirabilis S. aureus, B. subtilis, and B. licheniformis) at all concentrations $5-20 \mathrm{mg} / \mathrm{ml}$. However, more zone of inhibition was found at the highest concentration $(20 \mathrm{mg} /$ $\mathrm{ml}$ ) of vitamin C in all Gram-positive and Gram-negative bacterial strains. Vitamin $\mathrm{C}$ was found to be more stable at various temperatures $\left(4^{\circ} \mathrm{C}, 37^{\circ} \mathrm{C}\right.$, and $\left.50^{\circ} \mathrm{C}\right)$ and different $\mathrm{pH}$ (acidic and basic) values. Highest zone of inhibition was found at acidic $\mathrm{pH}$ against all bacterial strains. Therefore, vitamin $\mathrm{C}$ can be used in the forthcoming as an adjunct treatment option to combat the infections in humans caused by multidrug-resistant species of bacteria. Vitamin $C$ has the potential to be even more effective than antibiotics, in addition to its antimicrobial effects, as it directly supports the immune system. Very few studies about the antibacterial activity of individual vitamin $C$ have been found in the available literature whereas, the synergistic effect of vitamin $C$ with antibiotics was found. Therefore, it is further needs to search the probability of using vitamin $C$ safely as an effective antibacterial mediator against multidrug-resistant strains.

\section{Acknowledgements}

The authors wish to heartfelt thanks to all the authors for their assistance in this article. 


\section{References}

ABDULLAH, N.Y., 2009. Effect of some plant extracts against Staphylococcus aureus and Klebsiella pneumoniae. Iraqi Academic Science Journal, vol. 2, pp. 32-36.

AHMED, S.S., SHARIQ A., ALSALLOOM, A.A., BABIKIR, I.H. and ALHOMOUD, B.N., 2019. Uropathogens and their antimicrobial resistance patterns: relationship with urinary tract infections. International Journal of Health Sciences, vol. 13, no. 2, pp. 48-55. PMid:30983946.

AL-TALIB, H., YEAN, C.Y., AL-KHATEEB, A. and RAVICHANDRAN, M., 2013. Comparative evaluation of three different methods of genomic DNA extraction for Staphylococcus aureus. World Applied Sciences Journal, vol. 21, pp. 424-427.

ARAMWIT, P., BANG, N., RATANAVARAPORN, J. and EKGASIT, S., 2014. Green synthesis of silk sericin-capped silver nanoparticles and their potent anti-bacterial activity. Nanoscale Research Letters, vol. 9, no. 1, pp. 79. http://dx.doi.org/10.1186/1556-276X-9-79. PMid:24533676.

ARAMWIT, P., DAMRONGSAKKUL, S., KANOKPANONT, S. and SRICHANA, T., 2010. Properties and antityrosinase activity of sericin from various extraction methods. Biotechnology and Applied Biochemistry, vol. 55, no. 2, pp. 91-98. http://dx.doi. org/10.1042/BA20090186. PMid:20055756.

BISWAS, S., THOMAS, N., MANDAL, A., MULLICK, A., CHANDRA, D., MUKHERJEE, S. and MITRA, A.K., 2013. In vitro analysis of antibacterial activity of vitamin $C$ alone and in combination with antibiotics on gram positive rod isolated from soil of a dumping site of Kolkata. International Journal of Pharma and Bio Sciences, vol. 3, pp. 101-110.

EL-GEBALY, E., ESSAM, T., HASHEM, S. and EL-BAKY, R.A., 2012. Effect of levofloxacin and vitamin $C$ on bacterial adherence and preformed biofilm on urethral catheter surfaces. Journal of Microbiology and Biotechnology, vol. 4, pp. 131-136.

GOLONKA, I., OLEKSY, M., JUNKA, A., MATERA-WITKIEWICZ, A., BARTOSZEWICZ, M. and MUSIAŁ, W., 2017. Selected physicochemical and biological properties of ethyl ascorbic acid compared to ascorbic acid. Biological \& Pharmaceutical Bulletin, vol. 40, no. 8, pp. 1199-1206. http://dx.doi.org/10.1248/ bpb.b16-00967. PMid:28769001.

HAMADOU, A.H., HUANG, W.C., XUE, C. and MAO, X., 2020. Formulation of vitamin $C$ encapsulation in marine phospholipids nanoliposomes: characterization and stability evaluation during long term storage. Lebensmittel-Wissenschaft + Technologie, vol. 127, pp. 109439. http://dx.doi.org/10.1016/j.lwt.2020.109439.

HEMILÄ, H., 2017. Vitamin C and infections. Nutrients, vol. 9, no. 4 , pp. 339. http://dx.doi.org/10.3390/nu9040339. PMid:28353648.

HINDI, N.K.K. and CHABUCK, Z.A.G., 2013. Antimicrobial activity of different aqueous lemon extracts. Journal of Applied Pharmaceutical Science, vol. 3, pp. 74-80.

HOLLOWAY, A.C., GOULD, S.W., FIELDER, M.D., NAUGHTON, D.P. and KELLY, A.F., 2011. Enhancement of antimicrobial activities of whole and sub-fractionated white tea by addition of copper (II) sulphate and vitamin C against Staphylococcus aureus; a mechanistic approach. BMC Complementary and Alternative Medicine, vol. 11, pp. 115.

HONG, J.M., KIM, J.H., KANG, J.S., LEE, W.J. and HWANG, Y.I., 2016. Vitamin $C$ is taken up by human T cells via sodium-dependent vitamin C transporter 2 (SVCT2) and exerts inhibitory effects on the activation of these cells in vitro. Anatomy \& Cell Biology, vol. 49, no. 2, pp. 88-98. http://dx.doi.org/10.5115/acb.2016.49.2.88. PMid:27382510.
HWANG, H., LEE, H.J., LEE, M.-A., SOHN, H., CHANG, Y.H., HAN, S.G., JEONG, J.Y., LEE, S.H. and HONG, S.W, 2020. Selection and characterization of Staphylococcus hominis subsp. hominis WiKim0113 isolated from kimchi as a starter culture for the production of natural pre-converted nitrite. Food Science of Animal Resources, vol. 40, no. 4, pp. 512-526. http://dx.doi. org/10.5851/kosfa.2020.e29. PMid:32734260.

ISELA, N.N.R., SERGIO, N.C., JOSE, M.S.J., RENE, H.D. and CLAUDIO, C.R., 2013. Ascorbic acid on oral microbial growth and biofilm formation. The Pharma Innovation, vol. 2, pp. 104-109.

JEONG, Y.J., KIM, J.H., HONG, J.M., KANG, J.S., KIM, H.R., LEE, W.J. and HWANG, Y.I., 2014. Vitamin C treatment of mouse bone marrow-derived dendritic cells enhanced CD8+ memory $\mathrm{T}$ cell production capacity of these cells in vivo. Immunobiology, vol. 219, no. 7, pp. 554-564. http://dx.doi.org/10.1016/j. imbio.2014.03.006. PMid:24698552.

KALLIO, J., JAAKKOLA, M., MÄKI, M., KILPELÄINEN, P. and VIRTANEN, V., 2012. Vitamin C inhibits staphylococcus aureus growth and enhances the inhibitory effect of quercetin on growth of Escherichia coli in vitro. Planta Medica, vol. 78, no. 17, pp. 1824-1830. http://dx.doi.org/10.1055/s-0032-1315388. PMid:23059632.

KUIPER, C. and VISSERS, M., 2014. Ascorbate as a co-factor for Feand 2-oxoglutarate dependent dioxygenases: physiological activity in tumor growth and progression. Frontiers in Oncology, vol. 4, pp. 359. http://dx.doi.org/10.3389/fonc.2014.00359. PMid:25540771.

KWIECIŃSKA-PIRÓG, J., SKOWRON, K., BOGIEL, T., BIAŁUCHA, A., PRZEKWAS, J. and GOSPODAREK-KOMKOWSKA, E., 2019. Vitamin $C$ in the presence of sub-inhibitory concentration of aminoglycosides and fluoroquinolones alters Proteus mirabilis biofilm inhibitory rate. Antibiotics, vol. 8, no. 3, pp. 116. http:// dx.doi.org/10.3390/antibiotics8030116. PMid:31405233.

MAJTAN, J., SOJKA, M., PALENIKOVA, H., BUCEKOVA, M. and MAJTAN, V., 2020. Vitamin $C$ enhances the antibacterial activity of honey against planktonic and biofilm-embedded bacteria. Molecules, vol. 25, no. 4, pp. 992. http://dx.doi.org/10.3390/ molecules25040992. PMid:32102181.

MEHMETI, I., SOLHEIM, M., NES, I.F. and HOLO, H., 2013. Enterococcus faecalis grows on ascorbic acid. Applied and Environmental Microbiology, vol. 79, no. 15, pp. 4756-4758. http://dx.doi. org/10.1128/AEM.00228-13. PMid:23709509.

MOUSAVI, S., BERESWILL, S. and HEIMESAAT, M.M., 2019. Immunomodulatory and antimicrobial effects of vitamin C. European Journal of Microbiology \&' Immunology, vol. 9, no. 3, pp. 73-79. http://dx.doi.org/10.1556/1886.2019.00016. PMid:31662885.

NAMIOT, A., NAMIOT, D.B., BUCKI, R., KEMONA, A., KURYLONEK, A.J. and NAMIOT, Z., 2020. Vitamin C does not improve the efficacy of Helicobacter pylori eradication in smokers. Progress in Health Sciences, vol. 10, no. 1, pp. 77-81. http://dx.doi. org/10.5604/01.3001.0014.1918.

OPARA, L.U., AL-ANI, M.R. and AL-SHUAIBI, Y.S., 2009. Physicochemical properties, vitamin $C$ content, and antimicrobial properties of pomegranate fruit (Punica granatum L.). Food and Bioprocess Technology, vol. 2, no. 3, pp. 315-321. http:// dx.doi.org/10.1007/s11947-008-0095-5.

PRZEKWAS, J., WIKTORCZYK, N., BUDZYNSKA, A., WALECKAZACHARSKA, E. and GOSPODAREK-KOMKOWSKA, E., 2020. Ascorbic acid changes growth of food-borne pathogens in the early stage of biofilm formation. Microorganisms, vol. 8, no. 4, pp. 553-559. http://dx.doi.org/10.3390/microorganisms8040553. PMid:32290491. 
RAMOS, A.R., TAPIA, A.K.G., PINOL, C.M.N., LANTICAN, N.B., DEL MUNDO, M.L.F., MANALO, R.D. and HERRERA, M.U., 2019. Effects of reaction temperatures and reactant concentrations on the antimicrobial characteristics of copper precipitates synthesized using L-ascorbic acid as reducing agent. Journal of Science: Advanced Materials and Devices, vol. 4, pp. 66-71.

RANJAN, S., DASGUPTA, N., SAHA, P., RAKSHIT, M. and RAMALINGAM, C., 2012. Comparative study of antibacterial activity of garlic and cinnamon at different temperature and its application on preservation of fish. Advances in Applied Science Research, vol. 3, pp. 495-501.

SIMMONS, J.D., STEIN, C.M., SESHADRI, C., CAMPO, M., ALTER, G., FORTUNE, S., SCHURR, E., WALLIS, R.S., CHURCHYARD, G., MAYANJA-KIZZA, H., BOOM, W.H. and HAWN, T.R., 2018. Immunological mechanisms of human resistance to persistent Mycobacterium tuberculosis infection. Nature Reviews Immunology, vol. 18, no. 9, pp. 575-589. http://dx.doi. org/10.1038/s41577-018-0025-3. PMid:29895826.

STROHLE, A., WOLTERS, M. and HAHN, A., 2011. Micronutrients at the interface between inflammation and infection ascorbic acid and calciferol. Part 1: general overview with a focus on ascorbic acid. Inflammation and Allergy-Drug Targets, vol. 10, no. 1, pp. 54-63.

SWEILEH, W.M., AL-JABI, S.W., ZYOUD, S.H., SAWALHA, A.F. and ABU-TAHA, A.S., 2018. Global research output in antimicrobial resistance among uropathogens: a bibliometric analysis (2002-2016). Journal of Global Antimicrobial Resistance, vol.
13, pp. 104-114. http://dx.doi.org/10.1016/j.jgar.2017.11.017. PMid:29224787.

VAN GORKOM, G.N., KLEIN WOLTERINK, R.G., VAN ELSSEN, C.H., WIETEN, L., GERMERAAD, W.T. and BOS, G.M., 2018. Influence of vitamin C on lymphocytes: an overview. Antioxidants, vol. 7, no. 3, pp. 41. http://dx.doi.org/10.3390/antiox7030041. PMid:29534432.

VAN GORKOM, G.N.Y., LOOKERMANS, E.L., VAN ELSSEN, C.H. and BOS, G.M., 2019. The effect of vitamin C (ascorbic acid) in the treatment of patients with cancer: a systematic review. Nutrients, vol. 11, no. 5, pp. 977. http://dx.doi.org/10.3390/ nu11050977. PMid:31035414.

VERGHESE, R.J., MATHEW, S.K. and DAVID, A., 2017. Antimicrobial activity of Vitamin C demonstrated on uropathogenic Escherichia coli and Klebsiella pneumoniae. Journal of Current Research in Scientific Medicine, vol. 3, no. 2, pp. 88-93. http://dx.doi. org/10.4103/jcrsm.jcrsm_35_17.

VILCHÈZE, C., HARTMAN, T., WEINRICK, B. and JACOBS JUNIOR, W.R., 2013. Mycobacterium tuberculosis is extraordinarily sensitive to killing by a vitamin C-induced Fenton reaction. Nature Communications, vol. 4, no. 1, pp. 1881. http://dx.doi. org/10.1038/ncomms2898. PMid:23695675.

WOO, A., KIM, J.H., JEONG, Y.J., MAENG, H.G., LEE, Y.T., KANG, J.S., LEE, W.J. and HWANG, Y.I., 2010. Vitamin C acts indirectly to modulate isotype switching in mouse B cells. Anatomy \& Cell Biology, vol. 43, no. 1, pp. 25-35. http://dx.doi.org/10.5115/ acb.2010.43.1.25. PMid:21190002. 